\section{Utilization of human papillomavirus testing for cervical cancer prevention in a university hospital}

\author{
Utilização de método de biologia molecular para \\ papilomavírus humano na prevenção do câncer \\ de colo uterino em um hospital universitário
}

Rosekeila Simões Nomelini 1 Ana Cristina Macêdo Barcelos 1 Márcia Antoniazi Michelin 2 Sheila Jorge Adad 3 Eddie Fernando Candido Murta ${ }^{1}$

\section{Introduction}

1 Disciplina de Ginecologia e Obstetrícia, Universidade Federal do Triângulo Mineiro, Uberaba, Brasil. 2 Disciplina de Imunologia, Universidade Federal do Triângulo Mineiro, Uberaba, Brasil.

3 Disciplina de Patologia Especial, Universidade Federal do Triângulo Mineiro, Uberaba, Brasil.

Correspondence E. F. C. Murta Disciplina de Ginecologia e Obstetrícia, Universidade Federal do Triângulo Mineiro.

Av. Getúlio Guaritá s/n, Uberaba, $M G$ 38025-450, Brasil. eddiemurta@mednet.com.br

\begin{abstract}
This study aimed to evaluate the performance and cost of using polymerase chain reaction (PCR) and hybrid capture in the detection of cervical intraepithelial neoplasia (CIN) in patients with cytological abnormalities (ASCUS/lowgrade squamous intraepithelial lesion - LSIL), and the feasibility of implementing these methods in Brazil's Unified National Health System (SUS). Colposcopy gave a negative predictive value of $92.86 \%$ and efficiency of $87.8 \%$ for $d i$ agnosing CIN. The sensitivity of PCR and hybrid capture for detecting CIN was $83.33 \%$ and $66.67 \%$, respectively, and the negative predictive value for diagnosing CIN2/CIN3 was 100\% and 94.74\%, respectively. The annual cost for $80 \mathrm{pa-}$ tients was lower when all patients with ASCUS/ LSIL were referred for colposcopy than when HPV testing was performed and those with positive results were referred for colposcopy. Therefore, at present, it is financially unfeasible for the $\mathrm{Na}$ tional Health System to implement HPV testing to screen patients with cytological abnormalities (ASCUS/LSIL). However, considering that largescale use might make such methods cheaper, PCR should be the chosen method, since it is less expensive, more sensitive, and has a high negative predictive value.
\end{abstract}

Cervical Intraepithelial Neoplasia; Polymerase Chain Reaction; Colposcopy; Health Care Costs
Human papillomavirus (HPV) causes approximately 30 million new infections every year and is present in the female genital epithelium in some $10 \%$ of women 1 . This family of viruses infects a wide variety of organisms in a speciesspecific manner, and around 100 subtypes have been described in humans. Although the majority induces benign papillomas, some are classified as high-risk and contribute to the development of anogenital cancer. For example, HPV 16, 18, 45 , and 56 can lead to malignant transformation when they infect epithelial cells 2 . The majority of HPV genital infections are asymptomatic and self-limiting. Studies have shown that among women with normal oncological cytology, prevalence of HPV infection declines with age. Among patients with only cytological alterations due to HPV, regression reaches some $85 \%$ of cases 3,4 .

$\mathrm{HPV}$ infection is more frequent in young women with early sexual debut, smokers, and those with multiple sex partners. Smoking in particular is an independent factor related to precursor cervical lesions and invasive cancer 5,6,7.

Despite the impact of Pap smears on cervical cancer screening programs, the method has many limitations: high false-negative rates; the test's subjective nature; the need for frequent retesting; and wide inter-laboratory variation in sensitivity and specificity ${ }^{8}$. Some explanations for diagnostic errors related to cervical neopla- 
sia and precursor lesions by cytological methods are: lack of safe morphological criteria for microinvasion; lack of sampling the squamous-columnar junction; and scarcity of neoplastic cells in the sample 9 . There have thus been attempts to find alternatives to cytology as the primary screening test, as an adjunct for cytology to manage cases of atypical squamous cells of unknown significance (ASCUS), and for post-treatment follow-up.

Among patients with ASCUS cytology, management is a subject for discussion because of the occurrence of cervical intraepithelial neoplasia (CIN) during follow-up, ranging from $5 \%$ to $60 \% 10,11$. High-grade lesions are found in 10 to $15 \%$ of patients with ASCUS, while high-risk HPV is found in 40 to $60 \%$ of patients with ASCUS 12 .

As for management of patients with ASCUS and LSIL (low-grade squamous intraepithelial lesion), the ALTS study (ASCUS/LSIL Triage Stu$d y) 13$ was a large randomized trial designed to evaluate different methods for managing patients with cytological findings of ASCUS or LSIL. The Study considered three strategies: immediate colposcopy, repetition of the cervical smear, or HPV testing. The study concluded that HPV testing was worthless in women with LSIL, and the ASCCP (American Society for Colposcopy and Cervical Pathology) recommended that all patients with LSIL should be referred to colposcopy. For management of cytological findings of ASCUS, the ASCCP recommended that any of the three steps could be taken 14,15.

Manos et al. 16 studied a cohort of 46,009 women, of whom 995 had a cytological finding of ASCUS. In $6.7 \%$ of cases, CIN2, CIN3, or cancer was found by histology, and $39.5 \%$ of patients had high-risk HPV (HPV test). The sensitivity of HPV testing for high-grade dysplasia was $89.2 \%$, and specificity was $64.1 \%$. The percentage of patients referred to colposcopy was $39 \%$.

The present study is one component of the State Healthcare Agenda: Control of Priority Diseases and Complaints, in the context of testing women at an age when they are at risk of cervical cancer (Program for Cancer Prevention and Control and Oncological Care). This is a relevant public health issue, given that reduction in the transmission rate and especially in the female mortality rate resulting from this infection is a key goal on Municipal, State, and Federal healthcare agendas, as well as a World Health Organization (WHO) target.

The present study aimed to: verify the concordance between polymerase chain reaction (PCR) and hybrid capture for diagnosing HPV; compare the performance and cost of PCR and hybrid capture in the detection of CIN confirmed by biopsy in patients with cervical smear showing ASCUS and LSIL; and assess the feasibility of implementing the biomolecular method in the Unified National Health System (Sistema Único de Saúde - SUS) for the prevention of cervical cancer in patients with cytological findings of ASCUS and LSIL.

\section{Material and methods}

A prospective study was carried out at Universidade Federal do Triângulo Mineiro (UFTM) from December 2003 to July 2005. The study group consisted of patients $(n=80)$ aged 15 to 75 years with a diagnosis of ASCUS or LSIL based on cervical smears (inclusion criteria). The exclusion criteria were: previous ASCUS or LSIL, conization, or Chlamydia infection.

Routine annual cytological smears were colleted during gynecological examination (Gynecological Department, UFTM). Patients with a diagnosis of ASCUS or LSIL were referred to the Colposcopy Service (UFTM). All patients agreed to participate in the study. Data were collected on patient age, habits (smoking, drug use, and number of sex partners), living conditions, contraceptive methods, history of sexually transmitted diseases (STD), and use of hormone replacement therapy.

Patients who presented abnormalities in the colposcopic examination then underwent further procedures after having provided free and informed consent. These consisted of collecting the following: smears for cytology from the endocervix, ectocervix, and vagina; smears from the endocervix and ectocervix for hybrid capture and PCR; and biopsy of the lesion (when visible) for anatomopathological diagnosis.

The Rome Classification was used, dividing the colposcopic findings into normal (original squamous epithelium, columnar epithelium, and normal transformation zone) and abnormal (acetowhite, stippled, and mosaic-pattern epithelium, leukoplakia, iodine negative zone, and atypical vessels). These were then subdivided into greater or lesser alterations, depending on the degree to which the tissue was compromised 17 .

Cytological smears were evaluated according to morphological criteria: amphophilia, perinuclear halo, dyskeratosis, anisocytosis, nuclear criteria (binucleation or multinucleation), increased nucleus/cytoplasm ratio, anisokaryosis, hyperchromasia, nuclear atypia, and karyorrhexis 18,19 . The universally familiar Pap smear was also performed. Patients with cytological smears showing ASCUS/LSIL by any method (morphological criteria or Pap smear) and after being reviewed were included in the study. 
For PCR, samples were stored in Trizol at $-20^{\circ} \mathrm{C}$ and thawed when the DNA extraction was performed, at which time $200 \mu$ l of chloroform was added for every $1.0 \mathrm{ml}$ of Trizol collected. The DNA was added to an amplification solution according to the manufacturer's suggested protocol (Invitrogen, Carlsbad, USA). Table 1 shows the characteristics of the indicators synthesized for amplifying specific DNA fragments 20,21. After performing the PCR reaction, the amplification products were subjected to electrophoresis on $14 \%$ polyacrylamide gels and stained using silver. The Trackit 1 kB DNA ladder (Invitrogen, Carlsbad, USA) was used as a positive control pattern. $10.0 \mu \mathrm{l}$ of amplified sample and 3.0 $\mu$ l of buffer were homogenized and placed in each opening of the $14 \%$ polyacrylamide gel. The gel was run at 90 volts for approximately one hour, and then placed in a fixing solution for 15 minutes. This solution was discarded and silver solution was added for 15 minutes, followed by washing in Milli-Q $\mathrm{H}_{2} \mathrm{O}$ and incubation in a developing solution for approximately 15 minutes. The gel was returned to the fixing solution for 15 minutes, after which the resulting bands were observed.

For hybrid capture, the Hybrid Capture II apparatus was used together with the DML 2000 microplate system, with signal amplification by chemical luminescence according to the technique performed by Silva et al. 22. For HPV detection, the kit contains 18 viral types grouped in two probe pools. The probes for low-risk viruses included types $6,11,42,43$, and 44 , representing approximately $70 \%$ of this group of viruses. For the high-risk viruses, the system contained probes for types 16, 18, 31, 33, 35, 39, 45, 51, 52, $56,58,59$, and 68 , representing approximately $99 \%$ of this group of viruses. HPV sensitivity in the microplates was $1 \mathrm{pg} / \mathrm{ml}$.
The results were analyzed statistically. Tables were built with the results from HPV testing and colposcopy in relation to histology. Test performance included calculation of sensitivity, specificity, positive predictive value (PPV), negative predictive value (NPV), and efficiency (accuracy). Efficiency determined the percentage of correct diagnostic exams related to correct diagnosis. Women with negative colposcopy did not undergo biopsy, and these, together with women whose biopsies showed squamous metaplasia, alterations suggestive of HPV, or cervicitis, were defined as diagnostically negative. Women with a diagnosis of CIN1, CIN2, or CIN3 on biopsy were defined as diagnostically positive. Concordance between hybrid capture and PCR was calculated according to the following classification: kappa < 0.4 : weak concordance; $0.4 \leq \mathrm{kappa}<0.8$ : moderate concordance; $0.8 \leq \mathrm{kappa}<1$ : strong concordance; kappa $>1$ : perfect concordance 23 .

The study was approved by the UFTM Research Ethics Committee.

\section{Results}

Eighty patients were evaluated. Mean age was $33 \pm 12.21$ years (range: 15 to 74 ). Twenty-three patients $(28.75 \%)$ were smokers. Eight women (10\%) used hormonal contraceptives and one (1.25\%) was on hormone replacement therapy. With regard to previous sexually transmitted disease, two patients $(2.5 \%)$ reported a history of syphilis. Mean number of sex partners was $2 \pm 0.76$ (range: 1 to 5 ). Mean age at sexual debut was $15.79 \pm 2.01$ years (range: 13 to 26 ), and mean parity was $2.22 \pm 1.96$ (range: 0 to 12 ).

As for frequency of HPV diagnoses by PCR for each age group, the incidence decreased with ad-

Table 1

Characteristics of the synthesized indicators for amplifying specific DNA fragments.

\begin{tabular}{|c|c|c|c|c|}
\hline Primers & Sequence & $\begin{array}{c}\text { Size of the } \\
\text { amplified } \\
\text { product }\end{array}$ & $\begin{array}{c}\text { Annealing } \\
\text { temperature }\end{array}$ & Reference \\
\hline \multirow[t]{2}{*}{ HPV-16 } & $5^{\prime}=5^{\prime} \ldots$ ACC GAA ACC GGT TAG TAT AAA AGC $\ldots 3^{\prime}$ & & & \\
\hline & $3^{\prime}=5^{\prime} \ldots$ ATA ACT GTG GTA ACT TTC TGG GTC ...3' & $477 b p$ & $56^{\circ} \mathrm{C}$ & Sarkar et al. 20 \\
\hline \multirow[t]{2}{*}{ HPV-18 } & $5^{\prime}=5^{\prime} \ldots$ CGG TCG GGA CCG AAA ACG GTG...3' & & & \\
\hline & $3^{\prime}=5^{\prime} \ldots$ CGT GTT GGA TCC TCA AAG CGC GCC....3' & $422 \mathrm{bp}$ & $56^{\circ} \mathrm{C}$ & Sarkar et al. 20 \\
\hline \multirow[t]{2}{*}{$\beta$-actin } & $5^{\prime}=5^{\prime} \ldots$ GTG GGG CGC CCC AGG CAC CA.... $3^{\prime}$ & & & \\
\hline & $3^{\prime}=5^{\prime} \ldots$ CTC CTT AAT GTC ACG CAC GAT TTC $\ldots 3^{\prime}$ & $295 b p$ & $50^{\circ} \mathrm{C}$ & Tamim et al. 21 \\
\hline
\end{tabular}


vancing age, and $45.71 \%$ of cases were in patients aged 30 years or less.

Hybrid capture diagnosed 38 patients with high-risk HPV (47.5\%), while PCR diagnosed 70 positive cases (87.5\%). With regard to case distribution according to type of high-risk HPV diagnosed by PCR, 14 (17.5\%) of patients were only positive for HPV 16, while 56 patients (70\%) presented two types simultaneously.

Among the 80 patients with abnormal cytology, colposcopy was normal in 31 (38.75\%), inconclusive in 8 (10\%), and abnormal in 41 (51.25\%). Of the latter, there were stronger colposcopic findings in $13(16.25 \%)$ and weaker findings in 28 (35\%).

With regard to type of cytological diagnosis in the 80 patients, 36 patients (45\%) had ASCUS that was probably viral or neoplastic, 29 (36.25\%) had ASCUS that was probably reactive, and 15 (18.75\%) had LSIL (alterations suggestive of HPV in 12 women and CIN1 in three).

All patients with LSIL cytology presented positive PCR for high-risk HPV. With hybrid capture, eight patients $(53.33 \%)$ with LSIL according to cytology were positive for high-risk HPV, and 30 (46.15\%) with ASCUS on cytology were positive for high-risk HPV.

From comparative analysis of the 80 cases, using both hybrid capture and PCR for diagnosing HPV, 30 cases $(37.5 \%)$ were true positives and two $(2.5 \%)$ were true negatives. Hybrid capture sensitivity in relation to PCR was $42.8 \%$, and specificity was $20 \%$. Concordance of $40 \%$ (32 of 80) was observed between hybrid capture and PCR. The kappa coefficient was less than 0.4 , thus showing weak concordance.

Prevalence of CIN diagnosed by biopsy was 15\% (NIC in 12 of 80 patients). Even when hybrid capture gave a negative result, four (33.33\%) of 12 cases of CIN were positive on biopsy. When PCR gave a negative result, this number dropped to two (16.67\%). Of the 12 cases of CIN, 10 (83.33\%) were positive for HPV using PCR. Of the seven cases of CIN2 and CIN3, PCR was HPV-positive for all seven: six cases of HPV 16 and 18 and one case of HPV 16 (Table 2).

PCR performance for CIN detection was as follows: sensitivity $83.33 \%$; specificity $13.33 \%$; PPV 16.13\%; NPV 80\%; and efficiency 25\%. Hybrid capture performance for CIN detection was: sensitivity $66.67 \%$; specificity $56.67 \%$; PPV $23.53 \%$; NPV $89.47 \%$; and efficiency $58.33 \%$. When only CIN2 and CIN3 were considered to be positive diagnoses, the NPV increased to $100 \%$ and $94.74 \%$ for PCR and hybrid capture, respectively.

The Brazilian National Health System (SUS) spends the following amounts on each diagnostic method for HPV and uterine cervical lesions: gynecological consultation: $\mathrm{R} \$ 2.04$; cervicovaginal cytological tests: $\mathrm{R} \$ 5.37$; colposcopy: $\mathrm{R} \$ 1.69$; biopsy: R\$9.26 (information obtained from official SUS tables). The costs for PCR and hybrid capture (total materials used) are $\mathrm{R} \$ 27.13$ and $\mathrm{R} \$ 104.30$, respectively (currency exchange rate on November 11, 2005: U\$1.00 = R \$2.162).

The annual cost to the SUS for these 80 patients would be $\mathrm{R} \$ 869.76$ using a protocol whereby all patients with ASCUS/LSIL cytology were referred to colposcopy (Figure 1). The annual cost would be $\mathrm{R} \$ 2,931.30$ using a protocol whereby patients with ASCUS/LSIL cytology were only referred to colposcopy if they were PCR-positive for HPV 16 and 18 (Figure 2). The annual cost would be $\mathrm{R} \$ 8,757.70$ using a protocol whereby patients with ASCUS/LSIL cytology were only referred to colposcopy if they were positive for high-risk HPV according to hybrid capture (Figure 3).

Table 2

Diagnosis via biopsy in relation to PCR, hybrid capture, and cervicovaginal cytology

\begin{tabular}{|c|c|c|c|c|c|c|c|c|c|c|c|c|}
\hline \multirow[t]{3}{*}{ Biopsy } & \multicolumn{4}{|c|}{ PCR } & \multicolumn{4}{|c|}{ Hybrid capture } & \multicolumn{4}{|c|}{ Cytology } \\
\hline & \multicolumn{2}{|c|}{ Positive } & \multicolumn{2}{|c|}{ Negative } & \multicolumn{2}{|c|}{ Positive } & \multicolumn{2}{|c|}{ Negative } & \multicolumn{2}{|c|}{ ASCUS } & \multicolumn{2}{|c|}{ LSIL } \\
\hline & $\mathbf{n}$ & $\%$ & $\mathbf{n}$ & $\%$ & $\mathrm{n}$ & $\%$ & $\mathrm{n}$ & $\%$ & $\mathrm{n}$ & $\%$ & $\mathbf{n}$ & $\%$ \\
\hline Normal & 20 & 28.6 & 2 & 20.0 & 9 & 23.7 & 13 & 30.9 & 18 & 27.7 & 4 & 26.7 \\
\hline HPV & 5 & 7.1 & 2 & 20.0 & 6 & 15.8 & 1 & 2.4 & 6 & 9.2 & 1 & 6.7 \\
\hline CIN1 & 3 & 4.3 & 2 & 20.0 & 3 & 7.9 & 2 & 4.8 & 4 & 6.1 & 1 & 6.7 \\
\hline CIN2 & 4 & 5.7 & 0 & 0.0 & 3 & 7.9 & 1 & 2.4 & 2 & 3.1 & 2 & 13.3 \\
\hline CIN3 & 3 & 4.3 & 0 & 0.0 & 2 & 5.2 & 1 & 2.4 & 1 & 1.5 & 2 & 13.3 \\
\hline Not performed & 35 & 50.0 & 4 & 40.0 & 15 & 39.5 & 24 & 57.1 & 34 & 52.3 & 5 & 33.3 \\
\hline
\end{tabular}


Potential annual cost to the Brazilian National Health System (SUS) for 80 patients using a protocol whereby all patients with ASCUS/LSIL cytology were referred to colposcopy.

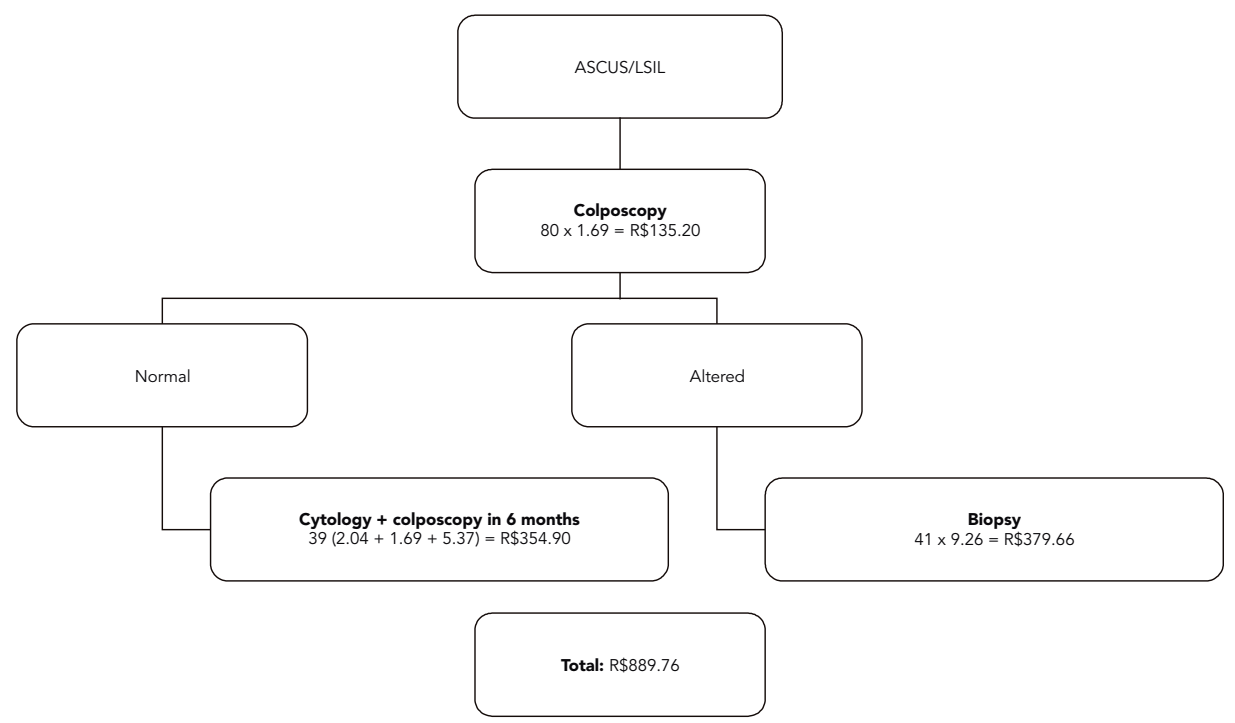

\section{Discussion}

According to the literature, HPV infection occurs most frequently in sexually active young women who smoke. Our study showed a high prevalence of high-risk HPV. Of the 12 cases of CIN, $10(83.33 \%)$ were positive for HPV according to PCR. The literature has shown that HPV is detected in approximately 80 to $100 \%$ of CIN cases. Cases that test negative may be due to the presence of new viral types (not included in the tests) or because the virus was not the etiological agent. In the case of hybrid capture, the lesions may present few viral copies, not yet detectable by this method.

Many HPV infections are transitory, eliminated by the immune system within a few months, without detectable residual lesions. HPV infection in young women generally tends to regress spontaneously, while among older women the virus is more prone to persist 24,25 . Frequency of infection thus decreases with increasing age, while the HPV clearance rate in younger patients is high 26 . This agrees with our findings, demonstrating peak frequency in the third decade of life and a subsequent decline. The positive predictive value of the HPV test thus increases with age, because the ratio of true positives (positive tests among women with high-grade lesions) to false positives increases among older women 27.

Olaniyan et al. 28 performed a meta-analysis to compare colposcopic findings with histological diagnosis and found $89 \%$ accuracy, with $61 \%$ exact correlation with histology. The sensitivity of colposcopy ranges from $87 \%$ to $99 \%$, with specificity of $26 \%$ to $87 \%$. In our study, colposcopy showed $83.33 \%$ sensitivity, $89.66 \%$ specificity, $76.92 \%$ positive predictive value, $92.86 \%$ negative predictive value, and $87.8 \%$ efficiency.

Comparing hybrid capture to PCR, Cuzick et al. 29 demonstrated $95 \%$ sensitivity, with a $2.3 \%$ false positive rate for hybrid capture. Venturoli et al. 30 showed $91.7 \%$ sensitivity and $95.4 \%$ specificity for this method. Most authors have demonstrated high concordance between hybrid capture and PCR, ranging from $76.5 \%$ to $90 \% 30,31,32$. Our study showed $40 \%$ concordance between PCR and hybrid capture. According to Cope et al. 33, PCR showed higher sensitivity for detecting the virus. In an analysis of sensitivity for detecting high-grade lesions, Nindl et al. 34 showed that hybrid capture failed to diagnose a large proportion of these lesions, as compared to PCR. Meanwhile, Kulmala et al. 35 showed $85 \%$ concordance between the two methods for diagnosing such lesions, and also a low positive predictive value 


\section{Figure 2}

Potential annual cost to the SUS for 80 patients using a protocol whereby patients with ASCUS/LSIL cytology were only referred to colposcopy if they were positive for HPV 16 and 18 by PCR.

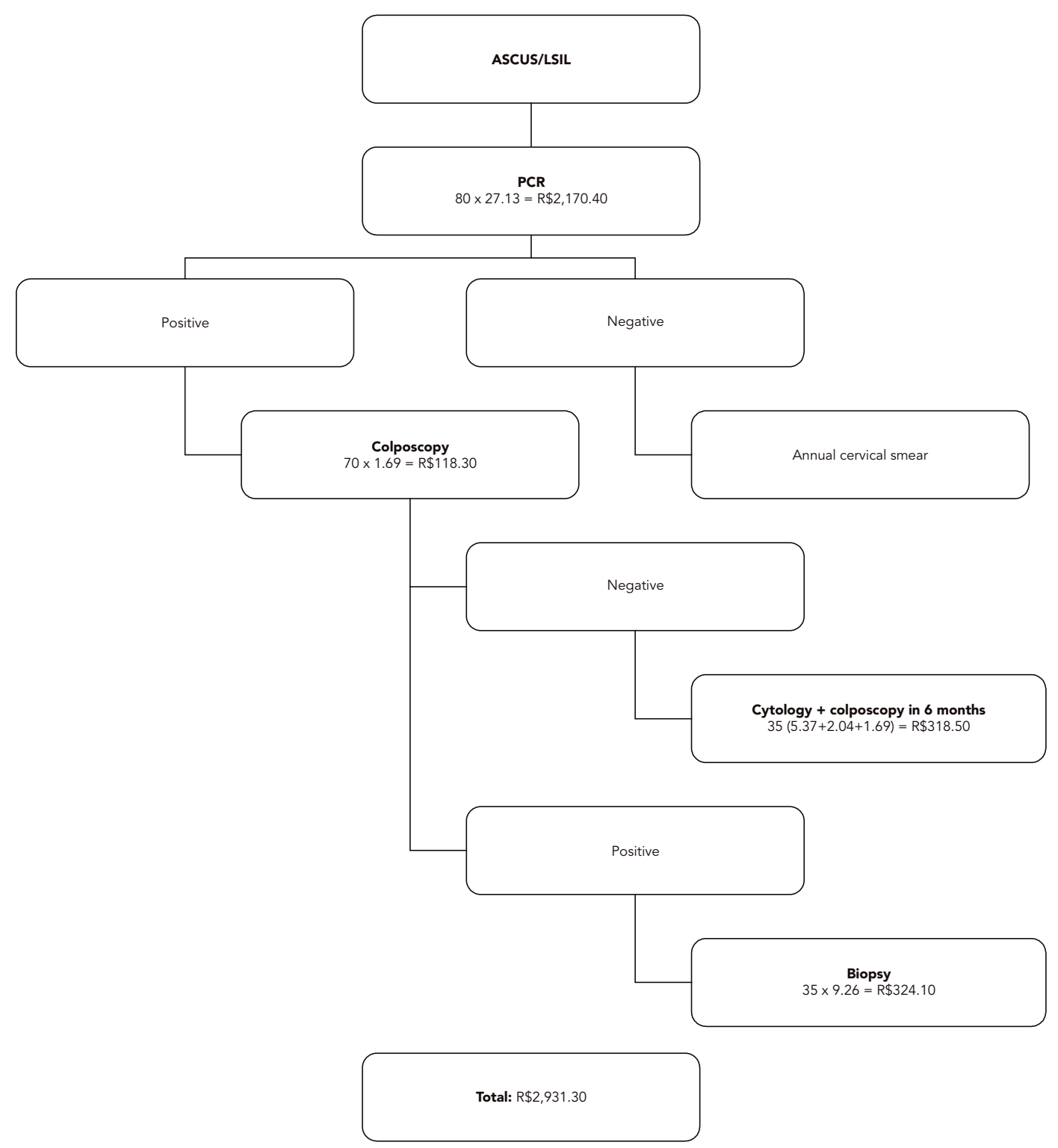

and a negative predictive value of nearly $100 \%$. Lonky et al. 36 demonstrated that hybrid capture gave a negative result in $25 \%$ of cases in which PCR tested positive for high-risk HPV in patients with ASCUS, thereby limiting its use.

ALTS obtained a negative predictive value of $99.50 \%$ in women with ASCUS, in relation to detection of CIN3 12. This finding agrees with our study, which showed a negative predictive value of $94.74 \%$ using hybrid capture and $100 \%$ using PCR for detecting CIN2 and CIN3. Most studies have shown negative predictive values ranging from $97 \%$ to $100 \% 29,37,38$. Thus, when a molecular test for HPV is negative, even if the cytological tests show ASCUS, the possibility of a high-grade lesion is very small. The specificity of hybrid cap- 
Figure 3

Potential annual cost to the SUS for 80 patients using a protocol whereby patients with ASCUS/LSIL cytology were only referred to colposcopy if they were positive for high-risk HPV by hybrid capture.

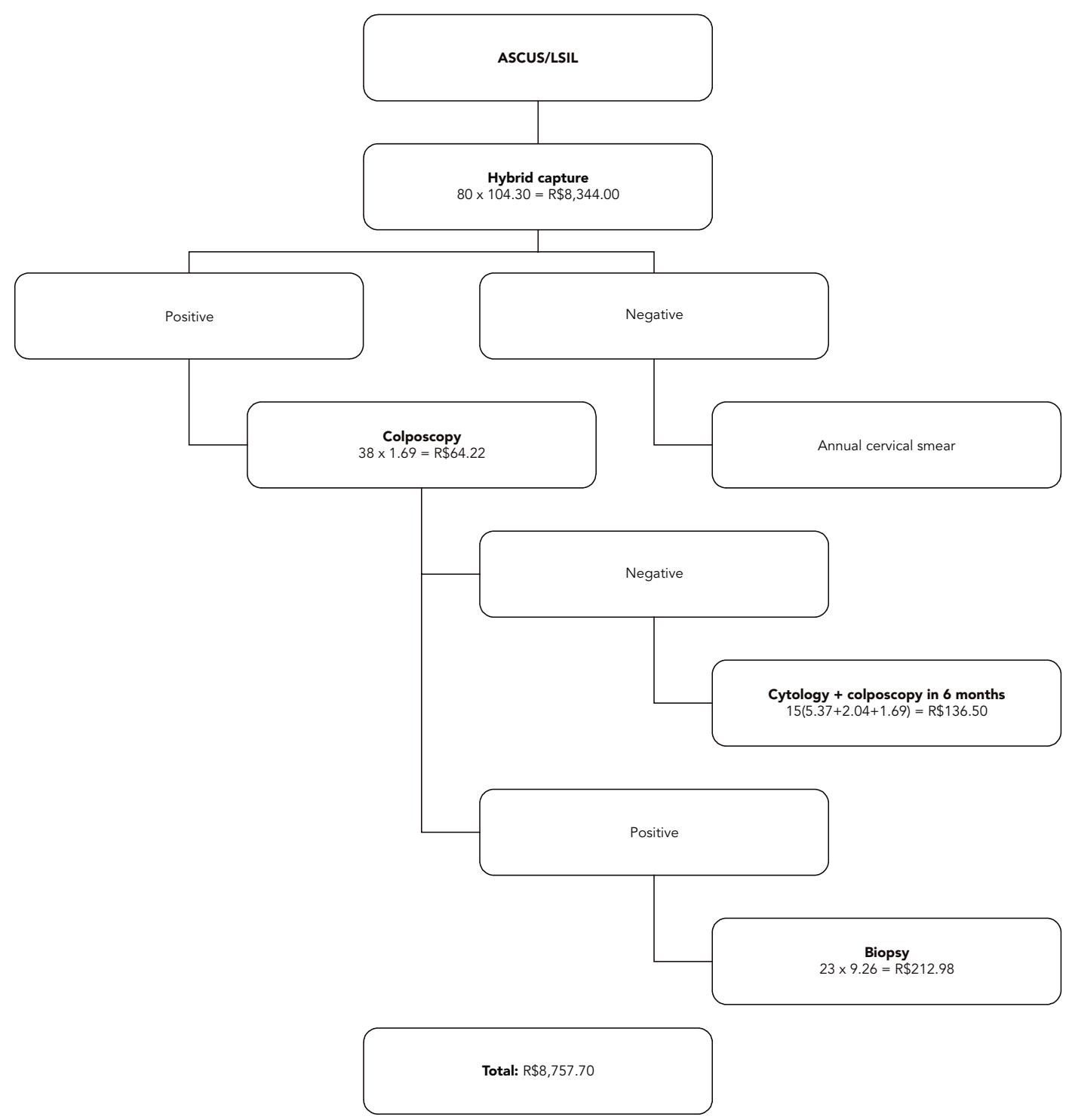

ture and PCR was low, i.e. there was a high falsepositive rate, thereby leading to greater need for repetition of tests or unnecessary referrals for colposcopy, besides increasing the patient's anxiety.

In our study, all cases of LSIL cytology were HPV-positive by PCR, while 53.33\% of cases were positive by hybrid capture; $84.61 \%$ and $46.15 \%$ of ASCUS cases were positive for high-risk HPV by PCR and hybrid capture, respectively. This very high result, particularly for PCR, can be explained by the fact that most of the women were less than 30 years old: in this age group, transitory and sub-clinical HPV infections are common 24,25,26. ALTS found that $83 \%$ of patients with LSIL had detectable HPV DNA, and since such positivity is so common, the authors suggested that the test should be limited to management of this group 13 . In contrast, $50.6 \%$ of women with ASCUS were 
positive for high-risk HPV, and among these patients, $5.10 \%$ had underlying CIN3 15 . Zerbini et al. ${ }^{39}$, using PCR to detect HPV 6, 11, 16, 18, 31, 33, and 45 , demonstrated $27.3 \%$ and $53.55 \%$ detection rates for ASCUS and LSIL, respectively.

Negative HPV testing in women with ASCUS or LSIL cytology could reduce the number of referrals for colposcopy. However, the identification of many transitory infections, which occur mainly before 30 years of age, greatly reduces the test's specificity for high-grade lesions 40 . Adding to cytology, biomolecular tests increase the detection rate for high-grade CIN and can prevent more cases of cancer than cytology alone. However, given the high rate of positive cases of high-risk HPV found by PCR in our study, for both LSIL and ASCUS, PCR would be more expensive than to refer patients directly to colposcopy. In Brazil, HPV testing is more expensive than cervical smear and colposcopy, although the cost could decrease if HPV testing were implemented on a large scale. Moreover, costs tend to level off or decrease if a test can reliably allow screening intervals to be extended.

Furthermore, HPV infection in young patients fluctuates greatly, with a high regression rate. Regression is difficult to evaluate, given the possibility of reactivation or reinfection. Thus, one must ask whether it would truly be safe to increase the screening interval in the face of a negative biomolecular test for HPV, if the possibility of reinfection exists. Evander et al. ${ }^{41}$ demonstrated that in $7.2 \%$ of their patients, a new type of virus was detected during follow-up. HPV infection was mainly associated with acquiring a new sex partner and having positive cytology. Schneider \& Koutsky 42 and Schneider et al. 43 also showed that the presence of HPV fluctuated during the period studied.

\section{Resumo}

O trabalho objetivou avaliar o desempenho e o custo do PCR e captura híbrida na deteç̧ão de neoplasia intraepitelial cervical (NIC) em pacientes com anormalidades citológicas (ASCUS/lesões de baixo grau - LBG), e a viabilidade da implantação destes métodos no serviço público de saúde. Observou-se valor preditivo negativo de 92,86\% e eficiência de 87,8\% da colposcopia para diagnóstico de NIC. A sensibilidade do PCR e captura híbrida na detecção de NIC foi de 83,33\% e 66,67\%, respectivamente. O valor preditivo negativo no diagnóstico de NICII III do PCR e captura híbrida foi de 100\% e 94,74\%, respectivamente. O custo anual das oitenta pacientes foi menor encaminhando-se todas as pacientes com ASCUS/
Developing countries need to assess the role of new technologies for cervical cancer prevention that can be useful in the healthcare context. However, a positive HPV test does not necessarily mean that the woman has CIN or cancer, but that she is at risk of developing these lesions. Any combination of tests will increase the sensitivity, while decreasing the specificity and increasing the cost. Despite the promise, there are insufficient studies to define the best combination.

Thus, despite the high negative predictive value of biomolecular methods for high-grade HPV infection, the possibility of reinfection, the high cost of the tests, and the better efficiency and lower cost of colposcopy are factors that demonstrate the unfeasibility of implementing biomolecular methods for HPV testing within the SUS, for patients with cytological findings of ASCUS or LSIL. However, with the possible cost reduction through large-scale use of the method, PCR should be the biomolecular method of choice, because of its high negative predictive value and lower cost as compared to hybrid capture.

In conclusion, PCR detected more high-risk HPV cases than hybrid capture; PCR and hybrid capture have a high negative predictive value for high-grade lesions, but the sensitivity of PCR is better; and at present, for cervical cancer prevention it is financially unfeasible for the SUS to implement molecular biology methods to screen patients with ASCUS and LSIL detected by cervical smear. Nonetheless, considering that largescale use could make such methods cheaper, PCR should be the method of choice, is less expensive, and shows better sensitivity and a high negative predictive value.
LBG à colposcopia do que se fossem realizados testes biomoleculares e encaminhando-se aquelas com resultados positivos à colposcopia. Portanto, por enquanto, é inviável financeiramente para o Sistema Único de Saúde a implantação de métodos de biologia molecular para pacientes com ASCUS e LBG à citologia cérvico-vaginal, mas considerando que o uso em grande escala poderia torná-los mais baratos, o PCR deveria ser o método escolhido, por ter menor custo, alto valor preditivo negativo e melhor sensibilidade.

Neoplasia Intra-Epitalial Cervical; Reação em Cadeia da Polimerase; Colposcopia; Custos de Cuidados de Saúde 


\section{Contributors}

R. S. Nomelini participated in data collection and analysis and in preparing the article. A. C. M. Barcelos collaborated in collecting the material and performing the colposcopy. M. A. Michelin collaborated in performing the PCR and hybrid capture. S. J. Adad participated in reading the slides and performing the hybrid capture. E. F. C. Murta contributed by orienting the research, performing the PCR and hybrid capture, conducting the statistical analysis, and preparing the article.

\section{References}

1. Koutsky LA, Galloway DA, Holmes KK. Epidemiology of genital human papillomavirus infection. Epidemiol Rev 1988; 10:122-63.

2. Schiffman MH, Brinton LA. The epidemiology of cervical carcinogenesis. Cancer 1995; 76:1888-901.

3. Murta EFC, Souza MAH, Falco VA, Lombardi W, Borges LS. Importância da infecção pelo papilomavírus humano na incidência da neoplasia intraepitelial cervical. J Bras Ginecol 1997; 107:361-6.

4. Murta EFC, França HG, Carneiro MC, Caetano MSSG, Adad SJ, Sousa MAH. Câncer do colo uterino: correlação com início da atividade sexual e paridade. Rev Bras Ginecol Obstet 1999; 21:555-9.

5. Murta EFC, Souza MAH, Adad SJ, Pires RA, Matthes AGZ. Influência da idade materna, do período gestacional e do número de gestações na infecção pelo papilomavírus humano. Rev Bras Ginecol Obstet 1998, 20:33-5.

6. Sardana S, Sodhani P, Agarwal SS, Sehgal A, Roy M, Singh V, et al. Epidemiologic analysis of Trichomonas vaginalis infection in inflammatory smears. Acta Cytol 1994; 38:693-7.

7. Derchain SF, Roteli-Martins CM, Syrjanen KJ, Abreu HJ, Martinez EZ, Alves VA. Association of oncogenic human papillomavirus HPV-DNA with high-grade cervical intraepithelial neoplasia (CIN 2 or 3): the role of cigarette smoking. Sex Transm Infect 1999; 75:406-8.

8. Denny LA, Wright TC. Human papillomavirus testing and screening. Best Pract Res Clin Obstet Gynaecol 2005; 20:501-15.

9. Adad SJ, Sousa MAH, Etchebehere RM, Saldanha JC, Falco VAA, Murta EFC. Cyto-histological correlation of 219 patients submitted to surgical treatment due to diagnosis of cervical intra-epithelial neoplasia. São Paulo Med J 2000; 117:81-4.

10. Morin C. Comparison of the hybrid capture test and polymerase chain reaction in identifying women with an ASCUS Pap smear who need colposcopy. J Lower Genital Tract Dis 1999; 3:231-8.

\section{Acknowledgements}

The authors wish to acknowledge the funding received from the Brazilian National Research Council (Conselho Nacional de Desenvolvimento Científico e Tecnológico - CNPq) and the Minas Gerais State ResearchFoundation (Fundação de Amparo à Pesquisa do Estado de Minas Gerais - FAPEMIG), grants 403059/2004-6 and $1740 / 2003$, respectively.

11. Eltabbakh GH, Lipman JN, Mount SL, Morgan A Significance of atypical squamous cells of undetermined significance on ThinPrep Papanicolaou smears. Gynecol Oncol 2000; 79:44-9.

12. Solomon D, Schiffman M, Tarone R. Comparison of three management strategies for patients with atypical squamous cells of undetermined significance: baseline results from a randomized trial. J Natl Cancer Inst 2001; 93:293-9.

13. The ALTS Group. Human papillomavirus testing for the triage of women with cytologic evidence of low-grade squamous intraepithelial lesions: baseline data from a randomized trial. J Natl Cancer Inst 2000; 92:397-402.

14. Wright Jr. TC, Schiffman M, Solomon D, Cox JT, Garcia F, Goldie S, et al. Interim guidance for the use of human papillomavirus DNA testing as an adjunct to cervical cytology for screening. Obstet Gynecol 2004;103:304-9.

15. Wright Jr. TC, Cox JT, Massad LS, Twiggs LB, Wilkinson EJ; ASCCP-Sponsored Consensus Conference. 2001 consensus guidelines for the management of women with cervical cytological abnormalities. JAMA 2002; 287:2120-9.

16. Manos MM, Kinney WK, Hurley LB, Sherman ME, Shieh-Nagai J, Kurman RJ, et al. Identifying women with cervical neoplasia: using human papillomavirus DNA testing for equivocal Papanicolaou results. JAMA 1999; 281:1605-10.

17. Stafl A, Wilbanks GD. An international terminology of colposcopy: report of the nomenclature committee of the International Federation of Cervical Pathology and Colposcopy. Obst Gynecol 1991; 77:313-4.

18. Roteli-Martins CM, Alves VA, Santos RT, Martinez EZ, Syrjanen KJ, Derchain SF. Value of morphological criteria in diagnosing cervical HPV lesions confirmed by in situ hybridization and hybrid capture assay. Pathol Res Pract 2001; 197:677-82. 
19. Yamamoto LS, Alves VA, Maeda MY, Longatto-Filho A, Utagawa ML, Eluf Neto J. A morphological protocol and guide-list on uterine cervix cytology associated to Papillomavirus infection. Rev Inst Med Trop Sao Paulo 2004; 46:189-93.

20. Sarkar FH, Crissman JD. Detection of human papilloma virus DNA sequences by polymerase chain reaction. Biotechniques 1990; 9:180-5.

21. Tamim H, Finan RR, Sharida HE, Rashid M, Almawi WY. Cervicovaginal coinfections with human papillomavirus and Chlamydia trachomatis. Diagn Microbiol Infect Dis 2002; 43:277-81.

22. Da Silva CS, Adad SJ, Hazarabedian-de-Souza MA, Macedo-Barcelos AC, Sarreta-Terra AP, Murta EF. Increased frequency of bacterial vaginosis and Chlamydia trachomatis in pregnant women with human papillomavirus infection. Gynecol Obstet Invest 2004; 58:189-93.

23. Arango HG. Bioestatística teórica e computacional. Rio de Janeiro: Editora Guanabara Koogan; 2001.

24. Hildesheim A, Schiffman MH, Gravitt PE, Glass AG, Greer CA, Zhang T, et al. Persistence of typespecific human papillomavirus infection among cytologically normal women. J Infect Dis 1994; 169:235-40

25. Ho GYF, Burk RD, Klein S, Kadish AS, Chang CJ, Palan P, et al. Persistent genital human papillomavirus infection is a risk factor for persistent cervical dysplasia. J Natl Cancer Inst 1995; 87:1365-71.

26. Elgren K, Kalantari M, Moberger B, Hagmar B, Dillner J. A population based 5-year follow-up study of cervical human papillomavirus infection. Am J Obstet Gynecol 2000; 183:561-7.

27. Sherman ME, Lorincz AT, Scott DR, Wacholder S, Castle PE, Glass AG, et al. Baseline cytology, human papillomavirus testing and risk for cervical neoplasia: a 10-year cohort analysis. J Natl Cancer Inst 2003; 95:46-52.

28. Olaniyan OB. Validity of colposcopy in the diagnosis of early cervical neoplasia - a review. Afr J Reprod Health 2002; 6:59-69.

29. Cuzick EB, Ho L, Sapper H, Mielzynska I, Lorincz A, Chan WK, et al. HPV testing in primary screening of older women. Br J Cancer 1999; 81:554-8.

30. Venturolli S, Bonvicini F, Giosa F, Pulvirente FR, Galli C, Musiani M, et al. Human papillomavirus DNA testing by PCR-ELISA and hybrid capture II from a single cytological specimen: concordance and correlation with cytological results. J Clin Virol 2002; 25:177-85

31. Bozzetti M, Nonnenmacher B, Mielzinska II, Villa L, Breitenbach VV, Prolla J. Comparison between hybrid capture II and polymerase chain reaction results among women at low risk for cervical cancer. Ann Epidemiol 2000; 10:466.

32. Nonogaki S, Wakamatsu A, Longatto Filho A, Pereira SM, Utagawa ML, Ferreira-Alves VA, et al. Hybrid capture II and polymerase chain reaction for identifying HPV infections in samples collected in a new collection medium: a comparison. Acta Cytol 2004; 48:514-20.
33. Cope JU, Hildesheim A, Schiffman MH, Manos MM, Lorincz AT, Burk RD, et al. Comparison of the hybrid capture tube test and PCR for detection of human papillomavirus DNA in cervical specimens. J Clin Microbiol 1997; 35:2262-5.

34. Nindl I, Zanm DM, Meijer CJ, Walboomers JM, Schneider A. Human papillomavirus detection in high-grade squamous intraepithelial lesions. Comparison of hybrid capture assay with a polymerase chain reaction system. Diagn Microbiol Infect Dis 1995; 23:161-4.

35. Kulmala SM, Syrjanen S, Shabalova I, Petrovichev $\mathrm{N}$, Kozachenko V, Podistov J, et al. Human papillomavirus testing with the hybrid capture 2 assay and PCR as screening tools. J Clin Microbiol 2004; 42:2470-5.

36. Lonky NM, Felix JC, Naidu YM, Wolde-Tsadik G. Triage of atypical squamous cells of undetermined significance with hybrid capture II: colposcopy and histologic human papillomavirus correlation. Obstet Gynecol 2003; 101:481-9.

37. Clavel C, Masure M, Bory JP, Putaud I, Mangeonjean C, Lorenzato M, et al. Human papillomavirus testing in primary screening for the detection of high-grade cervical lesions: a study of 7932 women. Br J Cancer 2001; 89:1616-23.

38. Franco EL. Primary screening of cervical cancer with human papillomavirus tests. J Natl Cancer Inst 2003; 92:818-25.

39. Zerbini M, Venturoli S, Cricca M, Gallinella G, De Simone P, Costa S, et al. Distribution and viral load of type-specific HPVs in different cervical lesions as detected by PCR-ELISA. J Clin Pathol 2001; 54:377-80.

40. Cuzick J, Szarewski A, Cubie H, Hulman G, Kitchener H, Luesley D, et al. Management of women who test positive for high-risk types of human papillomavirus: the HART study. Lancet 2003; 362:1871-6.

41. Evander M, Edlund K, Gustafsson A, Jonsson M, Karlsson R, Rylander E, et al. Human papillomavirus infection is transient in young women: a population-based cohort study. J Infect Dis 1995; 171:1026-30.

42. Schneider A, Koutsky L. Natural history and epidemiological features of genital HPV infection. In: Munoz, N, Bosh FX, Shah KV, Meheus A, editors. The epidemiology of cervical cancer and human papillomavirus. Lyon: International Agency for Research on Cancer; 1992. p. 25-52.

43. Schneider A, Kirchhoff T, Meinhardt G, Gissmann L. Repeated evaluation of human papillomavirus 16 status in cervical swabs of young women with a history of normal Papanicolaou smears. Obstet Ginecol 1992; 79:683-8.
Submitted on 06/Dec/2005
Final version resubmitted on 09/Oct/2006
Approved on 28/Nov/2006 